\title{
Trunk invertebrate faunas of Western Australian forests and woodlands: Influence of tree species and season
}

\author{
J. D. MAJER, ${ }^{1 \star}$ H. F. RECHER, ${ }^{2}$ R. GRAHAM ${ }^{1}$ AND R. GUPTA ${ }^{3}$ \\ ${ }^{1}$ Department of Environmental Biology, Curtin University of Technology, PO Box U1987, Perth, \\ Western Australia 6845, Australia (Email:j.majer@curtin.edu.au), ${ }^{2}$ School of Natural Sciences, \\ Edith Cowan University, Foondalup, Western Australia, Australia, and ${ }^{3}$ Department of Mathematics and \\ Statistics, Curtin University of Technology, Perth, Western Australia, Australia
}

\begin{abstract}
Trunk-associated invertebrates were sampled on two rough-barked tree species (jarrah, Eucalyptus marginata and marri, E. calophylla) at Karragullen, in the hills near Perth, Western Australia, and on these two species plus two smooth-barked species (wandoo, E. wandoo, and powderbark wandoo, E. accedens) at Dryandra, a drier site situated $150 \mathrm{~km}$ to the south-east. Invertebrates were sampled by intercept traps, which collect animals that attempt to land on the trunks, and photo-eclector bark traps, which collect invertebrates that move, or live, on the trunk. The range and abundance of invertebrates sampled was generally greater in the intercept than the bark traps. Invertebrate abundance and activity (but not biomass) on bark was strongly seasonal, with greater numbers being found during the moister periods. The two smooth-barked species supported, and were visited by, more invertebrates than the two rough-barked species. There was some evidence that jarrah supported more invertebrates than marri at both Karragullen and Dryandra, although the results were equivocal. Within the two smooth-barked species, wandoo tended to support more invertebrates than powderbark wandoo. These trends are discussed in terms of the characteristics of the bark of these trees and the environments in which they occur.
\end{abstract}

Key words: Eucalyptus forest, invertebrates, moisture gradient, tree trunk.

\section{INTRODUCTION}

Bark is an important component of forest and woodland ecosystems. As well as conferring various types of protection to trees, it serves as a link between the canopy and litter biota (Moeed \& Meads 1983; Hanula \& Franzreb 1998). Thus, captures in bark traps tend to include many species associated with the canopy, and others associated primarily with litter (Moeed \& Meads 1983; Hanula \& Franzreb 1998). Bark provides a wide range of refugia for various invertebrate species (Buchs 1990; Simon 1991) and also represents an important source of nutrition for such animals, either directly (Gullen \& Strong 1997), or through the epiphytes, fungi, lichens, algae and microorganisms that live on and within it (Jackson 1979; André 1985). In addition, bark acts as a highway or resting place for invertebrates that are moving within or across the habitat in which the trees occur (Funke 1977; Hanula \& Franzreb 1998; Proctor et al. 2002).

North American studies have indicated that the bark of more mature trees tends to provide for a greater diversity of invertebrates and biomass per unit area than does that of younger trees, with invertebrate biomass positively correlated with bark thickness and

$\star$ Corresponding author.

Accepted for publication May 2003. tree diameter (Hanula et al. 2000). The structural complexity of the bark also influences the invertebrate diversity found on it (Moeed \& Meads 1983; Nicolai 1989, 1993): tree species with complex bark tend to possess a greater diversity and biomass than smoothbarked trees (Nicolai 1989, 1993).

Although there is some information on the canopy invertebrate fauna of Australian eucalypt formations (Recher et al. 1996a; Majer et al. 2000), the only substantial studies on bark invertebrate faunas are those of Baehr (1990), Scarff et al. (1998) and Proctor et al. (2002). The lack of data on bark-invertebrates is an important gap in our knowledge of Australian forest and woodland ecosystems. The present paper compares invertebrate abundance and biomass at an ordinal level on the trunks of four of the major species of Eucalyptus in the south-west of Western Australia, two of which have rough bark and two have smooth bark. Specifically, it aims to document the variety and abundance of invertebrates that use, or visit the bark and show how this varies with season. It also examines whether these characteristics vary among tree species and, if so, what factors, including soil nutrients and bark characteristics (e.g. thickness, nutrients), might be responsible for any differences. A knowledge of site fertility is important, because this can influence nutrient levels in plants, with flow-on effects to the animals that feed upon them (Recher et al. 1996a). 
Other papers have considered the invertebrate fauna at the species level (Heterick et al. 2001; Majer et al. 2002).

\section{STUDY SITES AND METHODS}

\section{Sites}

In 1998, two study sites, approximately 3 ha in area, were selected for sampling of bark invertebrates (Fig. 1). The Karragullen site $\left(31^{\circ} 58^{\prime} \mathrm{S}, 116^{\circ} 03^{\prime} \mathrm{E}\right)$, is located close to Perth on the Darling Scarp, and Dryandra State Forest $\left(32^{\circ} 56^{\prime} \mathrm{S}, 117^{\circ} 11^{\prime} \mathrm{E}\right)$ is located close to the town of Narrogin. The Karragullen site is in jarrah/marri (E. marginata/E. calophylla) open-forest, and the Dryandra site is dominated on the slopes and flats by powderbark wandoo (E. accedens) and wandoo (E. wandoo) woodland. Jarrah and marri occur on the lateritic hilltops, with marri overlapping powderbark wandoo on mid-slopes at this site.

The precise location of each site was based on the availability of trees large enough for attaching invertebrate traps, accessibility, and fire history. Neither site had been burnt in the 2 years preceding the project, and no fires occurred during the study.

\section{Climate and vegetation structure}

Both sites experience a Mediterranean climate with warm summers and cool winters (Fig. 2). Rainfall occurs predominantly in the winter months, with annual averages of 1078 and $504 \mathrm{~mm}$, respectively, for Kalamunda and Narrogin, the closest meteorological recording stations (Fig. 1). Temperatures are similar between the two recording stations in all months (Fig. 2).

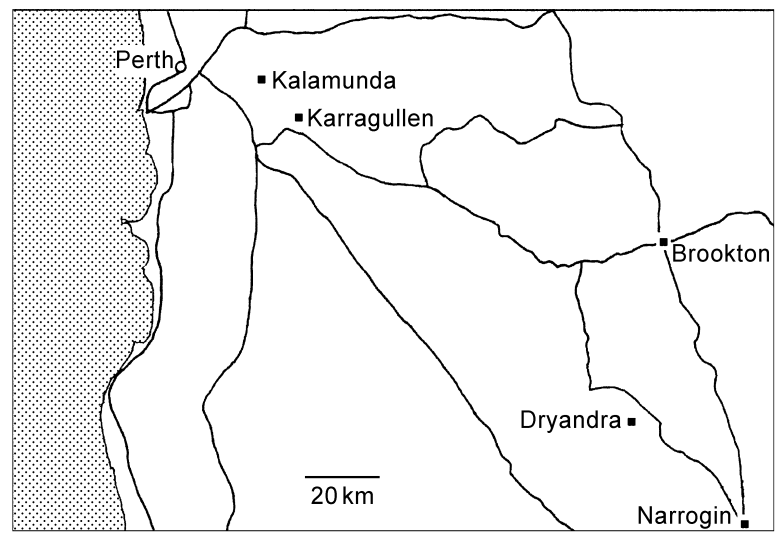

Fig. 1. Map of study sites at Karragullen and Dryandra State Forest. Also shown are the locations of the three meteorological recording stations.
Canopy cover, shrub cover and tree basal area were measured at each site in autumn 2000. The canopy cover for foliage over $2 \mathrm{~m}$ was measured using a crownometer. Samples were taken at random points throughout the study site until the number of records equalled 100 for the most common tree species. The shrub layers were measured using the point method developed by Levy and Madden (1933). Percentage cover was calculated by using a thin pole, graduated into $20-\mathrm{cm}$ bands, and placed vertically at intervals of $5 \mathrm{~m}$ along a series of transects. The numbers of contacts by vegetation were recorded for each band. One hundred points were sampled along three 100-m transects. Each of the transects was separated by a distance of $50 \mathrm{~m}$ and was positioned so as to capture the variation in vegetation across the site.

Tree basal area was estimated using a dendrometer. A mean value was calculated from five readings taken at random locations in each site. The diameters of 100 randomly selected trees with trunks $>21 \mathrm{~cm}$ circumference at $1.5 \mathrm{~m}$ were measured in each site to provide a profile of species and age class distribution.
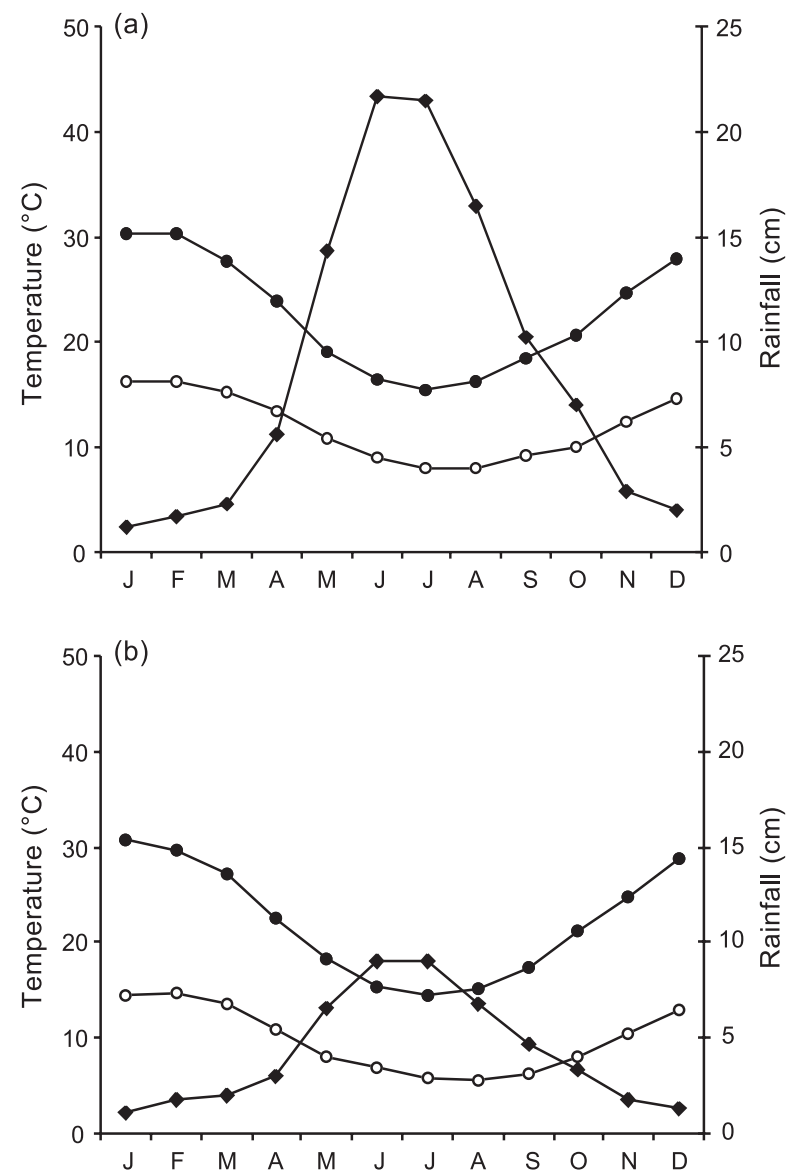

Fig. 2. Long-term averages for $(\diamond)$ monthly rainfall, mean monthly maximum temperature, and $(O)$ minimum temperature for (a) Kalamunda $\left(31^{\circ} 58^{\prime} \mathrm{S}, 116^{\circ} 03^{\prime} \mathrm{E}\right)$ and (b) Narrogin $\left(32^{\circ} 56^{\prime} \mathrm{S}, 117^{\circ} 11^{\prime} \mathrm{E}\right.$ ) (source Australian Bureau of Meteorology). 
Soil

Ten 54-mm diameter, 100-mm deep soil samples were taken with a corer from random locations at the Karragullen site and each of the hilltop, mid-slope and base of hill positions at the Dryandra site. Broadly speaking, these positions, respectively, corresponded to the locations of the jarrah/marri, powderbark wandoo and wandoo trees. All material was sealed in paper bags and oven dried at $72^{\circ} \mathrm{C}$ to constant weight, in preparation for analysis of macro- and micronutrients.

\section{Selection of trees}

Ten mature jarrah and marri trees were selected at Karragullen, and 10 of each of these two species plus 10 wandoo and 10 powderbark wandoo were selected at Dryandra. The two species at Karragullen grew as an

(a)

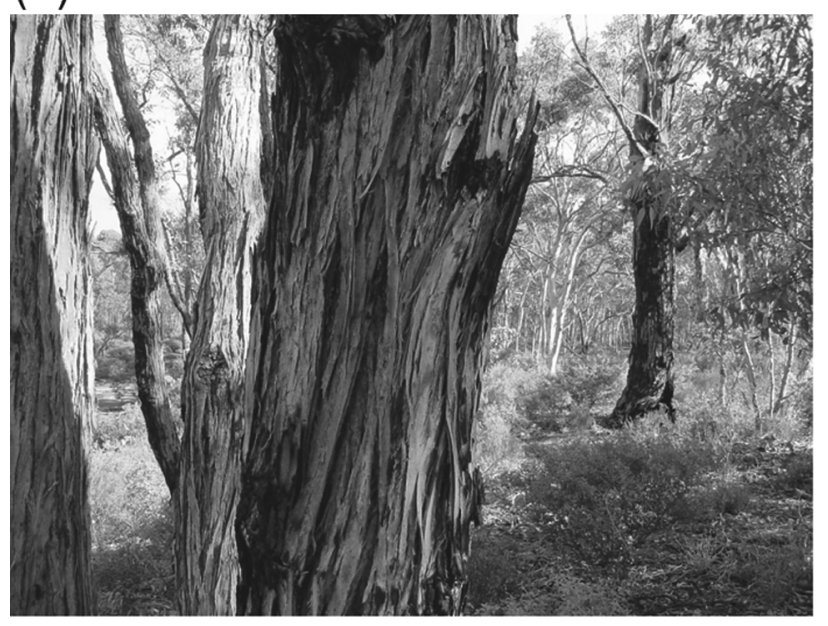

(c)

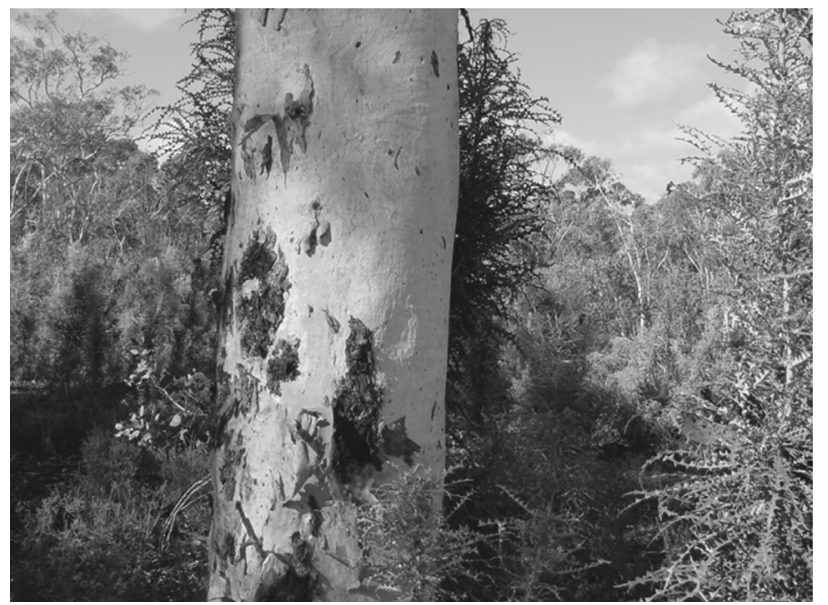

admixture, so sampling of both species occurred in an identical area. At Dryandra, marri and particularly jarrah tended to grow on the lateritic hilltops, powderbark wandoo on the mid-slopes and wandoo on the bases of the slopes. Consequently, the sampled trees of each species tended to be sourced from these three regions, although there was considerable overlap between marri and jarrah, and marri and powderbark wandoo. The distance between the furthest trees of any species was no more than $300 \mathrm{~m}$. Within the limits imposed by the total number of available trees, specimens with similar trunk diameter $1.5 \mathrm{~m}$ above ground were selected.

\section{Characteristics of the bark}

The bark types of the four species are shown in Fig. 3. Brooker and Kleinig (1990) described the bark of

\section{(b)}

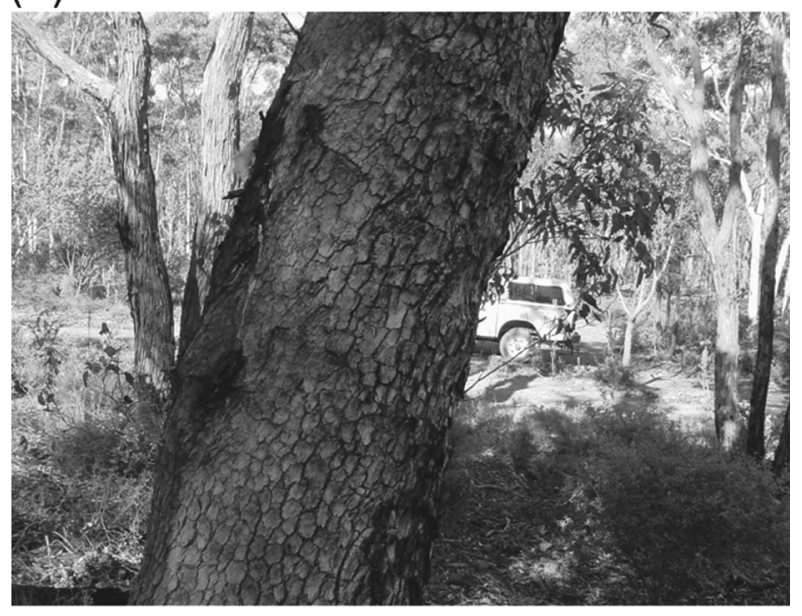

(d)

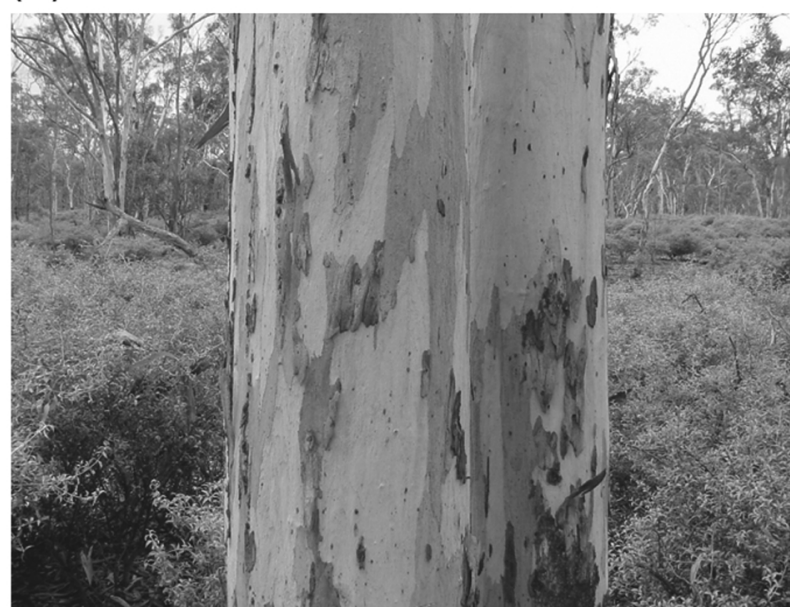

Fig. 3. Views of trunks of the four tree species that were sampled: (a) jarrah; (b) marri; (c) powderbark wandoo; (d) wandoo. 
mature jarrah as rough, dark grey, fibrous, usually held flat in longitudinal strips; marri as rough, tessellated, grey brown to dark brown; powderbark wandoo as smooth, pink to pinkish, very powdery; and wandoo as smooth, white, grey, creamy, salmon pink or pale orange. Both of the smooth-trunk species possess exfoliating bark.

The thickness and chemical characteristics of the bark of the trees were measured on 10 trees of each species at Dryandra. Except where indicated, all measurements and samples were taken at $1.5 \mathrm{~m}$. The thickness of the corky tissue, or phellem, was measured at five locations on each tree with a probe and ruler. This was not possible for the two smooth-barked species, as most of this layer exfoliates. Consequently, the thickness of five samples of freshly fallen bark beneath each tree was measured with a micrometer.

Ten samples of corky tissue were removed from jarrah and marri trees for nutrient analysis. Freshly fallen bark was collected from beneath 10 of each of the other two species for the same purpose. In addition, five samples of live bark, or phelloderm, were cut out of the powderbark wandoo and wandoo trees to compare with the exfoliated part. All material was sealed in paper bags, oven dried at $72^{\circ} \mathrm{C}$ to constant weight and then ground up in a Wiley-type mill with a $1-\mathrm{mm}$ sieve for subsequent analysis of nutrients.

The 10 samples of dead bark from each tree species were analysed separately, thus enabling statistical analyses to be performed. The five live bark samples for the two smooth-barked species were bulked, so no information on variance was available for this material.

\section{Invertebrate sampling}

Invertebrates were sampled using two methods, a modified photo-eclector bark trap (Moeed \& Meads 1983) and a Perspex intercept trap (Fig. 4). The traps

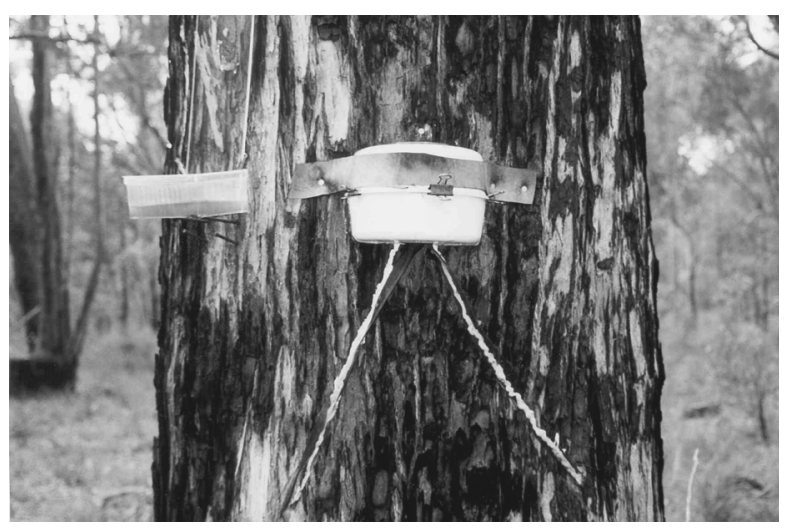

Fig. 4. Photo-eclector bark trap and Perspex intercept trap on the side of a jarrah trunk. were attached to the northern side of trunks at $1.5 \mathrm{~m}$. Where the bark was unsuitable for attaching traps because of damage or surface irregularities, the traps were placed on the first suitable surface of the trunk moving in an easterly direction around the tree. Sets of traps were installed on 10 trees of each tree species at the two sites.

Bark traps were designed to catch invertebrates living on the bark or moving across its surface. Bark traps were nailed to the bark. A pair of $90 \mathrm{~cm}$ long, $>40 \mathrm{~mm}$ high drift fences, with a distance of $90 \mathrm{~cm}$ across the two free edges, was used to channel invertebrates moving vertically up the trunk into the trap. Fences were nailed into grooves cut into the rough bark or nailed into place on the smooth-barked trees. Sealant was used to fill gaps. Invertebrates caught in the bark traps were preserved in 50\% ethylene glycol or propylene glycol until cleared.

Intercept traps were designed to catch invertebrates landing on the bark surface. A flat piece of Perspex $(130 \mathrm{~mm} \times 300 \mathrm{~mm})$ was nailed to the trunk to the left and slightly above the bark traps. A collecting tray was attached to the bottom edge of the Perspex using alligator clips and supported underneath by nails. The collecting tray, which contained ethylene glycol or propylene glycol, had small perforations half-way up the sides to allow overflow of excess liquid while retaining any trapped invertebrates. Invertebrate sampling was initiated in October 1998 and terminated in October 1999. Sampling took place at eight-week intervals, with traps remaining active for two weeks before being cleared. Samples were transferred to $70 \%$ ethanol for sorting. The samples for spring (October) 1998 and winter (August) 1999 were sorted to morphospecies; all other samples were sorted to ordinal level. Larvae of endopterygote orders were recorded separately from adults. Invertebrates were sorted into length classes, and biomass calculated using appropriate formulae (Calver \& Wooller 1982; Gowing \& Recher 1984, 1985). This was not possible for the October 1998 and August 1999 samples, as the material had been sent to taxonomists for confirmation of identifications.

\section{Data analysis}

Percentage plant cover and mean basal area values were calculated for the Karragullen and Dryandra sites. Mean bark thickness and bark nutrient levels were calculated for each of the four tree species at Dryandra, and mean soil characteristics were calculated for the three hillside positions. Then, using data for the dead or exfoliated bark only, and data for each soil characteristic, one-way ANOVA was performed to compare tree species, and Fisher's post-hoc test was applied to the results. The data were log-transformed to conform 
to the assumptions of the ANOVA prior to performing these analyses.

For each tree species during each sampling event, an estimate of invertebrate biomass was calculated. A power model was used to convert the abundance of invertebrates in each body length class to weight (Gowing \& Recher 1984), and estimated weights of the eight classes were added to give the total weight (mg dry weight).

Means and standard errors for total invertebrates, invertebrate biomass and abundance within each invertebrate 'order' were calculated for each tree species at each site during each of the seven sampling periods. Data for trunk and intercept traps were treated separately in all of the following analyses.

Invertebrate totals, biomasses and ordinal counts were compared for trunk and intercept traps on jarrah versus marri at Karragullen, and among all four tree species at Dryandra, using two-way analyses of variance (ANOVA), with season included as a second

Table 1. Total percentage of tree trunks for each tree species, and also total percentage canopy cover, percentage shrub cover and tree basal area, at the two study sites in Western Australia

\begin{tabular}{lcc}
\hline Tree species & Karragullen & Dryandra \\
\hline Eucalyptus calophylla & 8.1 & 8.7 \\
Eucalyptus marginata & 48.6 & 6.3 \\
Eucalyptus wandoo & 0.0 & 28.3 \\
Eucalyptus accedens & 0.0 & 40.0 \\
Eucalyptus astringens & 0.0 & 1.3 \\
Allocasuarina fraseriana & 15.8 & 0.0 \\
Allocasuarina huegeliana & 0.0 & 11.7 \\
Banksia grandis & 22.4 & 0.0 \\
Persoonia longifolia & 1.8 & 0.0 \\
Dead trunk & 3.2 & 3.3 \\
Total canopy cover $(\%)$ & 65 & 50 \\
Total shrub cover $(\%)$ & 62 & 37 \\
Basal area $\left(\mathrm{m}^{2}\right)$ & 24.9 & 13.3 \\
\hline
\end{tabular}

variable. The data were log-transformed to conform to the assumptions of the ANOVA. Tests were only performed on commonly sampled 'orders' (present in more than four seasons). It was generally not possible to perform post-hoc tests to identify those tree species that differed from each other in terms of a particular 'order', as disorderly interactions frequently occurred between tree species and season. Consequently, a series of one-way ANOVA were performed for each season separately, and Fisher's post-hoc test was applied to the results. Where excessive numbers of zeros occurred, non-parametric Friedman two-way tests and KruskalWallis one-way tests were used. The Mann-Whitney $U$-test was used at Karragullen, where only two tree species were involved.

\section{RESULTS}

\section{Vegetation}

Tree canopy cover and tree basal area was greater at Karragullen than Dryandra (Table 1). Basal area was almost twice as high at Karragullen as at Dryandra and reflected the fact that the former was an open forest, whereas the latter was a woodland. The composition of the understorey also differed between the sites, with Allocasuarina fraseriana, Banksia grandis and, to a lesser extent, Persoonia longifolia comprising the mid-storey at Karragullen, but A.huegliana dominating the midstorey at Dryandra (Table 1). Shrub cover was generally lower at Dryandra than at Karragullen (Table 1).

\section{Soil}

Mean soil nutrients, conductivity and $\mathrm{pH}$ are shown in Table 2. With the exception of potassium, levels of all

Table 2. Mean nutrient levels at Karragullen and hillside positions at Dryandra, Western Australia

\begin{tabular}{|c|c|c|c|c|c|c|}
\hline Nutrient & $\begin{array}{l}\text { Karragullen } \\
\quad(\mathrm{J} / \mathrm{M})\end{array}$ & $\begin{array}{l}\text { Hill-top } \\
(\mathrm{J} / \mathrm{M})\end{array}$ & $\begin{array}{c}\text { Dryandra } \\
\text { Mid-slope } \\
\text { (PW) }\end{array}$ & $\begin{array}{l}\text { Hill-base } \\
\text { (W) }\end{array}$ & $F$ & Significance \\
\hline Nitrate - N & $<1.00$ & $<1.00^{\mathrm{a}}$ & $<1.00^{\mathrm{a}}$ & $2.22^{\mathrm{a}}$ & 1.00 & NS \\
\hline Ammonium - N & 9.00 & $6.11^{\mathrm{a}}$ & $7.22^{\mathrm{a}}$ & $6.00^{\mathrm{a}}$ & 1.58 & NS \\
\hline Phosphorus & 13.70 & $5.78^{b}$ & $9.22^{\mathrm{a}}$ & $5.56^{\mathrm{b}}$ & 6.83 & $\star \star \star$ \\
\hline Potassium & 82.60 & $132.78^{\mathrm{a}}$ & $177.00^{\mathrm{a}}$ & $94.11^{\mathrm{b}}$ & 9.47 & $\star \star \star$ \\
\hline Sulphur & 9.04 & $8.26^{\mathrm{a}}$ & $7.10^{\mathrm{a}}$ & $6.66^{\mathrm{a}}$ & 2.24 & NS \\
\hline Iron & 1450.80 & $631.89^{\mathrm{a}}$ & $1170.78^{a}$ & $1036.44^{\mathrm{a}}$ & 1.93 & NS \\
\hline Organic carbon (\%) & 4.68 & $4.02^{\mathrm{b}}$ & $5.17^{\mathrm{a}}$ & $3.21^{\mathrm{b}}$ & 6.40 & $\star \star$ \\
\hline
\end{tabular}

Except where indicated, values are in $\mathrm{mg} \mathrm{kg}^{-1}$. For each nutrient at Dryandra, positions that share the same letter have mean nutrient levels ('a' denotes highest mean) that have been shown by one-way ANovA (d.f. =9) and Fisher's post-hoc test not to differ significantly from each other. $\mathrm{J}$, jarrah; $\mathrm{M}$, marri; W, wandoo; PW, powderbark wandoo. ${ }^{\star} P<0.05$; ${ }^{\star \star} P<0.01$; $\star \star \star P<0.005$; NS, not significant; NT, not tested as all values were equal. 
nutrients were higher at Karragullen than at the corresponding jarrah/marri region at Dryandra. Although there were differences in phosphorus, potassium, carbon, conductivity and $\mathrm{pH}$ between sample sites at Dryandra, there were no consistent trends along the slope.

\section{Features of the bark}

The phellem of the rough-barked jarrah and marri were of similar thickness, and thicker than the exfoliated bark of the smooth-barked species (Table 3). Wandoo had a thicker exfoliated bark than powderbark wandoo.

There were significant differences in bark nutrients between tree species (Table 3). Nutrient levels in jarrah and marri were relatively similar, although marri bark contained higher quantities of nitrogen and calcium and lower quantities of sulphur than jarrah. Differences between the two smooth-barked species were greater, with wandoo bark containing more nitrogen, calcium, manganese and iron, and less sulphur than powderbark wandoo. There were few consistent differences between bark nutrients of the rough-barked versus the smoothbarked species, although wandoos had significantly more sodium and magnesium than marri and jarrah.

With the exception of nitrogen in wandoo, and iron in both species, nutrient levels were higher in live than dead bark of the smooth-barked species. As with exfoliated bark, there was no consistent difference in nutrient levels between the two smooth-barked species, although manganese and iron were once again found at higher levels and sulphur at lower levels in wandoo than in powderbark wandoo. By contrast, nitrogen levels were at lower levels in wandoo than powderbark wandoo live bark, even though the reverse was found in the dead bark.

\section{Invertebrates}

The total number of invertebrates sampled on each tree species and their distribution among the various taxonomic categories, at both Karragullen and Dryandra, are shown in Table 4. In decreasing order of abundance, the most common groups in the intercept traps were Diptera, Collembola, Hymenoptera (ants and wasps), Coleoptera, Hemiptera, Acarina, Thysanoptera, Araneae and Psocoptera. The corresponding ranking for bark traps was Collembola, Hymenoptera (ants), Hemiptera, Diptera, Acarina, Araneae, Coleoptera, Hymenoptera (wasps), Lepidoptera and Blattodea. The breadth of phyla, classes and orders was greater in intercept than bark traps, with Nematoda, Mollusca and Tardigrada only being present in the former. The seasonal means for total invertebrates and invertebrate biomass at Karragullen and Dryandra are shown in Figs 5 and 6, respectively. A summary of the results of the statistical tests for influence of tree species and season on individual 'orders' is given in Table 5. The complete tables of results of these tests may be obtained by email from the corresponding author.

\section{Karragullen}

In bark traps at Karragullen, there was no significant effect on invertebrate totals of tree species, but there was a significant seasonal effect (Fig. 5a, Table 5),

Table 3. Thickness and nutrient content of bark of jarrah, marri, powderbark wandoo and wandoo trees collected at Dryandra during May 2001

\begin{tabular}{|c|c|c|c|c|c|c|c|c|}
\hline & \multicolumn{4}{|c|}{ Dead or exfoliated bark } & \multicolumn{4}{|c|}{ Live bark } \\
\hline & $\mathrm{J}$ & M & PW & W & $\mathrm{F}$ & Sig. & PW & W \\
\hline $\begin{array}{l}\text { Thickness of dead or } \\
\text { exfoliated bark (mm) }\end{array}$ & $10-20$ & $10-20$ & 0.8 & 2.2 & NT & NT & NM & NM \\
\hline Nitrogen $(\%)$ & $0.120^{\mathrm{b}}$ & $0.211^{\mathrm{a}}$ & $0.134^{\mathrm{b}}$ & $0.195^{\mathrm{a}}$ & 6.1 & $\star \star \star$ & 0.140 & 0.108 \\
\hline Phosphorus (\%) & $0.010^{\mathrm{a}}$ & $0.010^{\mathrm{a}}$ & $0.010^{\mathrm{a}}$ & $0.010^{\mathrm{a}}$ & 0.0 & NS & 0.022 & 0.021 \\
\hline Potassium (\%) & $0.010^{\mathrm{a}}$ & $0.010^{\mathrm{a}}$ & $0.010^{\mathrm{a}}$ & $0.010^{\mathrm{a}}$ & 0.0 & NS & 0.119 & 0.118 \\
\hline Sulphur (\%) & $0.041^{\mathrm{a}}$ & $0.021^{\mathrm{b}}$ & $0.034^{\mathrm{a}}$ & $0.014^{\mathrm{b}}$ & 16.6 & $\star \star \star$ & 0.043 & 0.020 \\
\hline Sodium (\%) & $0.021^{\mathrm{b}}$ & $0.017^{\mathrm{b}}$ & $0.063^{\mathrm{a}}$ & $0.075^{\mathrm{a}}$ & 18.3 & $\star \star \star$ & 0.162 & 0.197 \\
\hline Calcium (\%) & $0.048^{\mathrm{d}}$ & $0.075^{\mathrm{c}}$ & $0.325^{\mathrm{b}}$ & $1.206^{\mathrm{a}}$ & 75.7 & $\star \star \star$ & 0.918 & 1.247 \\
\hline Magnesium (\%) & $0.019^{\mathrm{b}}$ & $0.031^{\mathrm{b}}$ & $0.131^{\mathrm{a}}$ & $0.157^{\mathrm{a}}$ & 62.7 & $\star \star \star$ & 0.281 & 0.187 \\
\hline Copper (\%) & $1.900^{\mathrm{a}}$ & $2.092^{\mathrm{a}}$ & $1.445^{\mathrm{a}}$ & $1.462^{\mathrm{a}}$ & 0.8 & NS & 2.920 & 2.880 \\
\hline Zinc $\left(\mathrm{mg} \mathrm{kg}^{-1}\right)$ & $3.09^{\mathrm{a}}$ & $4.29^{\mathrm{a}}$ & $2.44^{\mathrm{a}}$ & $4.31^{\mathrm{a}}$ & 2.5 & NS & 23.65 & 37.61 \\
\hline Manganese $\left(\mathrm{mg} \mathrm{kg}^{-1}\right)$ & $1.72^{\mathrm{cd}}$ & $1.61^{\mathrm{d}}$ & $8.79^{\mathrm{b}}$ & $50.70^{\mathrm{a}}$ & 203.3 & $\star \star \star$ & 24.10 & 61.90 \\
\hline Iron $\left(\mathrm{mg} \mathrm{kg}^{-1}\right)$ & $157.10^{\mathrm{a}}$ & $188.98^{a}$ & $59.01^{b}$ & $89.95^{\mathrm{a}}$ & 6.0 & $\star \star \star$ & 50.90 & 51.70 \\
\hline Boron $\left(\mathrm{mg} \mathrm{kg}^{-1}\right)$ & $2.94^{\mathrm{b}}$ & $6.30^{\mathrm{a}}$ & $6.35^{\mathrm{a}}$ & $7.57^{\mathrm{a}}$ & 8.6 & $\star \star \star$ & 9.94 & 10.01 \\
\hline
\end{tabular}

In 'Dead or exfoliated bark' columns, tree species that share the same letter have mean nutrient levels ('a' denotes highest mean) that have been shown by one-way ANOva (d.f. = 3) and Fisher's post-hoc test to not differ significantly from each other. J, jarrah; M, marri; W, wandoo; PW, powderbark wandoo. ${ }^{\star \star \star} P<0.005$; NS, not significant; NT, not tested; NM, not possible to measure. 


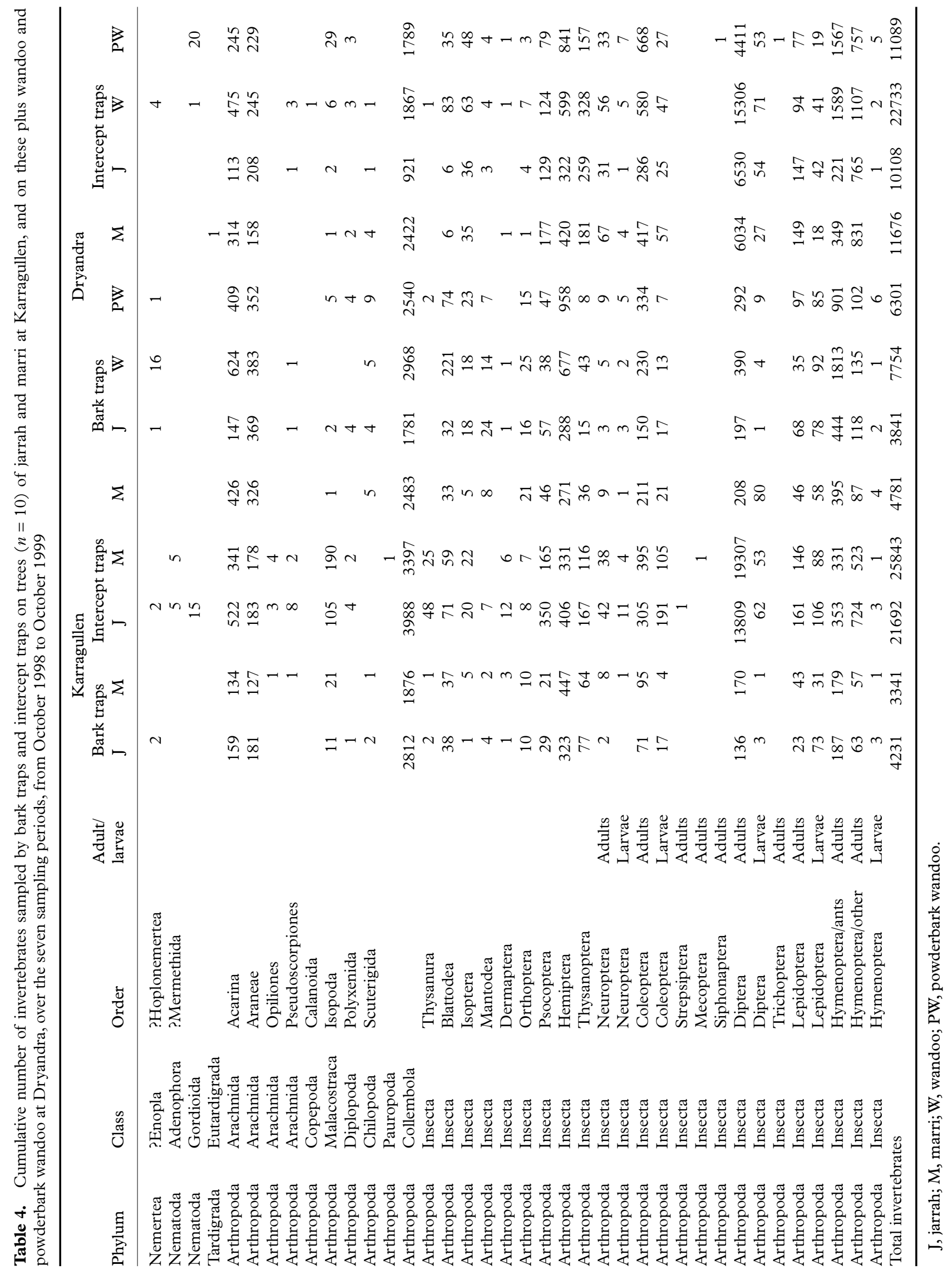


which reflects the June 1999 peak. This peak was not reflected in the biomass, where there was neither a tree species nor a seasonal effect (Fig. 5c, Table 5). Oneway ANOVA indicated significant differences in barktrap totals for December 1998 and June 1999 (Fig. 5a), with abundances being greater on jarrah than marri. No differences were found for biomass (Fig. 5c).

There was no significant effect of tree species, but a significant effect of season in intercept traps (Fig. 5b, Table 5), although the peak was in August 1999, two months later than in the bark traps (Fig. 5a). Biomass in intercept traps also exhibited a significant seasonal effect (Table 5), although there were several peaks throughout the sampling period which were not in phase on the two tree species (Fig. 5d). Numbers of invertebrates were significantly greater on jarrah than marri in December 1998 and April 1999. Biomass was also significantly greater on jarrah in December 1998.

Of the taxa tested, eight exhibited differences in abundance between tree species in bark traps, and nine in intercept traps (Table 5). All taxa in intercept traps, and all taxa except Isopoda and Psocoptera in bark traps, exhibited significant seasonal variation (Table 5), with trends generally reflecting those in Figs 5a,b. The number of months when any taxon exhibited a difference between tree species was relatively low. Consideration of the prevailing rank of individual taxa between the two tree species suggested that jarrah tended to support higher numbers of invertebrates than marri. This was true for both trap types, although application
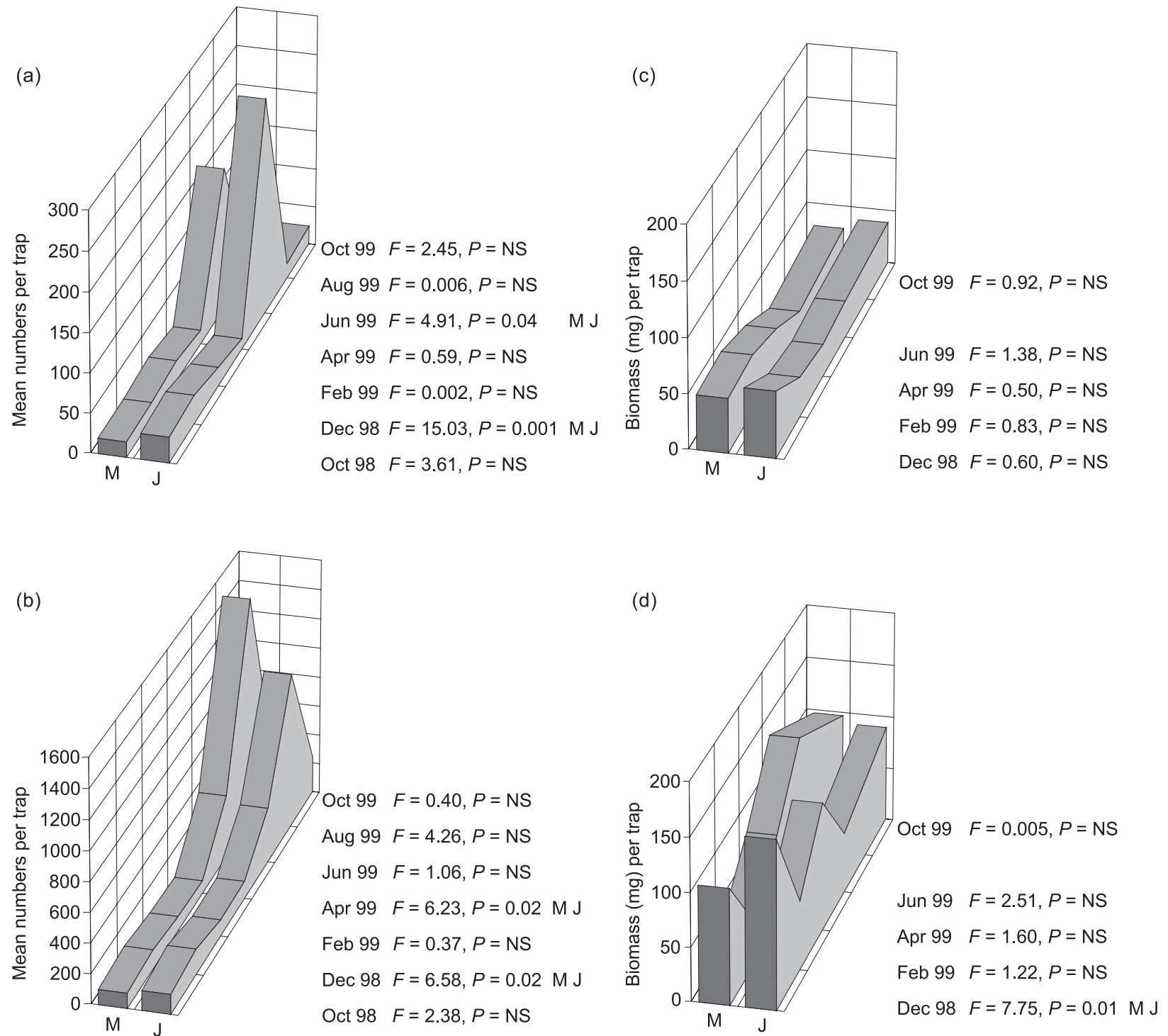

Fig. 5. Seasonal changes in the total number and total biomass of invertebrates in $(a, c)$ bark and $(b, d)$ intercept traps on jarrah (J) and marri $(\mathrm{M})$ trees $(n=10)$ at Karragullen. The results of the one-way ANOva for each sampling period are shown and, where significant, tree species are ranked from that supporting fewest invertebrates (left) to that supporting the most (right). Note that biomass data are unavailable for October 1998 and August 1999. 
of the binomial signs test indicated that the trend across taxa was not significant.

\section{Dryandra}

There was a significant effect of tree species and season for totals (Fig. 6a, Table 5) and biomass (Fig. 6c, Table 5) in bark traps at Dryandra. In both cases, the seasonal trends were in phase across tree species, resulting in significant interaction effects. Peaks in abundance occurred in October 1998 and June 1999 (Fig. 6a), although peaks in biomass were less obvious (Fig. 6c). The one-way ANOVA indicated significant differences among tree species in abundance for five of the sampling periods and of biomass for two of the periods. In all but one case, wandoo supported the highest invertebrate loads, and powderbark wandoo, or sometimes marri, supported the second highest levels (Figs 6a,c).

Invertebrate totals in intercept traps at Dryandra (Fig. 6b) exhibited effects of tree species and season (Fig. 6b and Table 5), with seasonal peaks in October 1998 and October 1999. Trends among tree species were not always in phase, resulting in an interaction effect. Effects of tree species and season were also evident for biomass (Fig. 6d and Table 5), although the season when biomass was universally higher was equivocal, leading to interaction effects. The one-way ANOVA for individual seasons indicated that wandoo received the highest visitations by invertebrates, followed by powderbark wandoo and, to a lesser extent, marri or jarrah (Fig. 6b,d).

Of the taxa tested, 12 exhibited differences among tree species in bark traps, and 14 in intercept traps
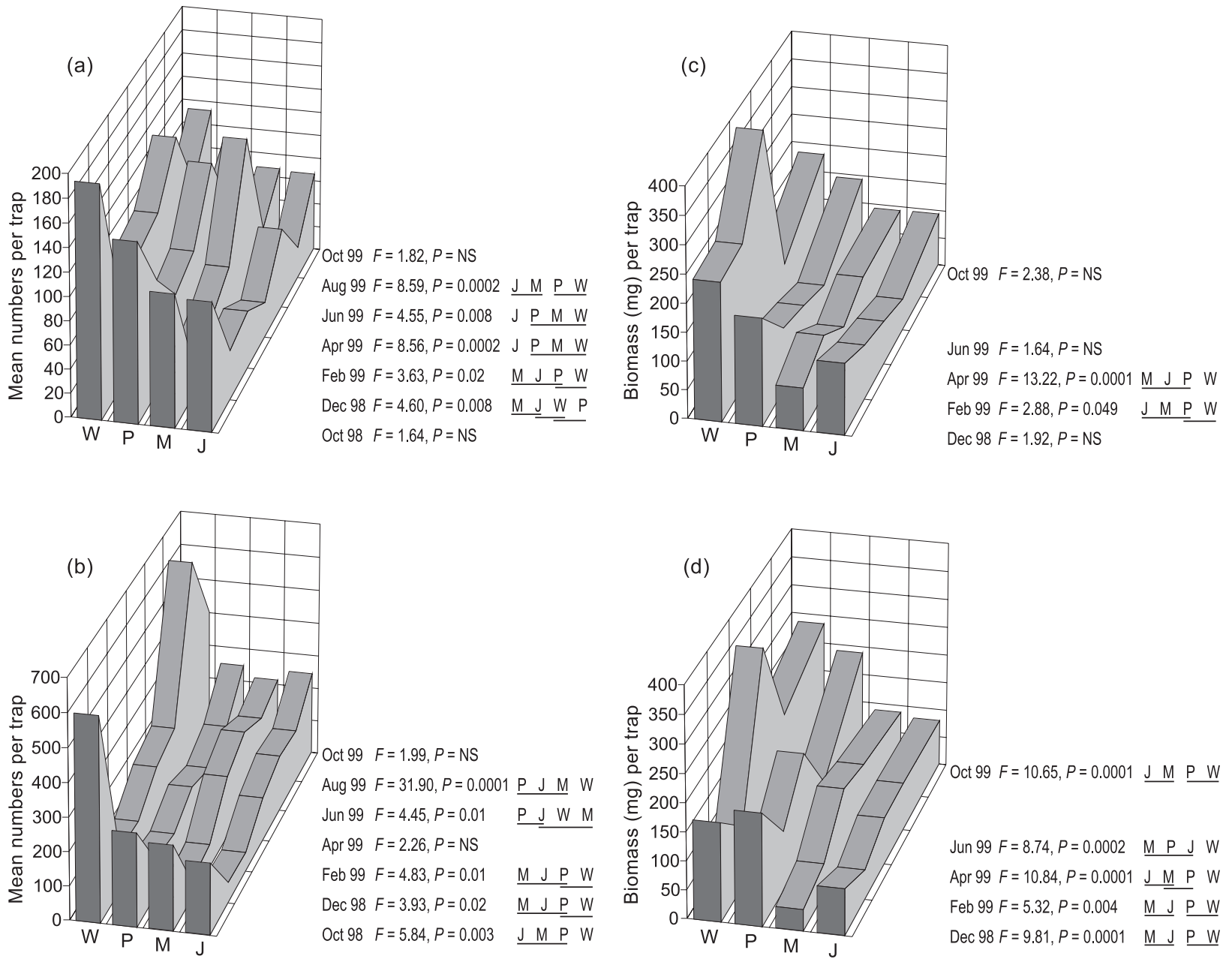

Fig. 6. Seasonal changes in the total numbers and total biomass of invertebrates in the $(a, c)$ bark and $(b, d)$ intercept traps on jarrah $(\mathrm{J})$, marri $(\mathrm{M})$, powderbark wandoo $(\mathrm{P})$ and wandoo $(\mathrm{W})$ trees $(n=10)$ at Dryandra. The results of the one-way ANOvA for each sampling period are shown and, where significant, tree species are ranked from those supporting the fewest invertebrates (left) to those supporting the most (right). The horizontal bars below the tree species are derived from Fisher's post-hoc tests and link those tree species that do not significantly differ from each other in terms of their invertebrate loads. Note that biomass data are unavailable for October 1998 and August 1999. 
(Table 5). All taxa except Isopoda in intercept traps exhibited significant seasonal variation (Table 5). The number of periods when significant differences among tree species was demonstrated was higher at Dryandra than at Karragullen.

The agreement between ordinal rankings across tree species were compared by means of Kendall's coefficient of concordance. Rankings were significant for bark $(n=4, k=12, W=0.325, P<0.01)$ and intercept $(n=4, k=14, W=0.176, P<0.05)$ traps. In both cases, this trend resulted from wandoo and powderbark wandoo supporting higher numbers of individuals within orders than jarrah or marri. There was also a trend of more invertebrates within 'orders' on jarrah than marri, and on wandoo than powderbark wandoo, although these were not significant by the binomial signs test.

\section{DISCUSSION}

A number of trends were evident in the invertebrate data from the bark and intercept traps.

First, the range and abundance of invertebrates was generally greater in the intercept than the bark traps. The array of animals in bark traps from the four eucalypts sampled corresponded to the range of trophic groups caught in bark traps in New Zealand (Moeed \& Meads 1983) and in North America (Hanula \& Franzreb 1998). Specifically, the fauna largely comprises fungivores/decomposers, herbivores and predators/parasitoids (Heterick et al. 2001), although some groups are undoubtedly omnivorous. The greater abundance and variety of invertebrates in intercept traps highlights the fact that bark receives more visitations by invertebrates than the numbers of animals actually living there. This confirms the importance of bark (tree trunks) for the movement of invertebrates within forests and woodlands. Tree trunks not only provide refugia and resting places, but are places where individuals congregate and may be important for locating mates.

Diptera and Hymenoptera (wasps) were less common in the bark traps than they were at intercept traps, which suggests that many of them were transients. Hanula and Franzreb (1998) also noted that the flight traps that they used sampled disproportionately higher numbers of wasps and other animals that feed in other strata of the forest when compared with the samples from bark traps. By contrast, some taxa captured abundantly in intercept traps, such as Collembola and ants, are not transients and would have entered the traps because of their sheer abundance.

Second, invertebrate abundance and activity (but not biomass) on bark was seasonal, with greater numbers found during the moister periods. Hanula and Franzreb (1998) also noted strong seasonality of North American bark invertebrates, although, as in the study reported here, trends in numbers did not necessarily coincide with those in biomass. The peak in abundance at Karragullen was during winter (June in bark traps, August in intercept traps). By contrast, at the drier Dryandra site, there were peaks in winter and spring (June and October in bark traps, October in

Table 5. Summary of significant $\left(^{\star}\right)$ statistical results for the comparison of selected invertebrates sampled by bark (B) and intercept (I) traps on marri and jarrah at Karragullen and on these plus powderbark wandoo and wandoo at Dryandra

\begin{tabular}{|c|c|c|c|c|c|c|c|c|c|c|}
\hline & & & \multicolumn{4}{|c|}{ Karragullen } & \multicolumn{4}{|c|}{ Dryandra } \\
\hline & & & \multicolumn{2}{|c|}{ Species } & \multicolumn{2}{|c|}{ Season } & \multicolumn{2}{|c|}{ Species } & \multicolumn{2}{|c|}{ Season } \\
\hline & & & B & I & $\mathrm{B}$ & I & $\mathrm{B}$ & I & B & I \\
\hline Total Invertebrates & & & NS & NS & $\star$ & $\star$ & $\star$ & $\star$ & $\star$ & $\star$ \\
\hline Invertebrate biomass & & & NS & NS & NS & $\star$ & $\star$ & $\star$ & $\star$ & $\star$ \\
\hline \multirow[t]{2}{*}{ Arachnida } & Acarina & & NS & NS & $\star$ & $\star$ & $\star(5)$ & $\star(5)$ & $\star$ & $\star$ \\
\hline & Araneae & & $\star(2)$ & NS & $\star$ & $\star$ & NS & $\star(3)$ & $\star$ & $\star$ \\
\hline Crustacea & Isopoda & & NS & $\star(1)$ & NS & $\star$ & NT & NS & NT & NS \\
\hline Collembola & & & $\star(1)$ & NS & $\star$ & 夫 & $\star(5)$ & $\star(3)$ & $\star$ & $\star$ \\
\hline \multirow[t]{11}{*}{ Insecta } & Blattodea & & NS & $\star(1)$ & $\star$ & 夫 & $\star(2)$ & $\star(3)$ & $\star$ & $\star$ \\
\hline & Psocoptera & & NS & $\star(2)$ & NS & $\star$ & $\star(2)$ & $\star(3)$ & $\star$ & $\star$ \\
\hline & Homoptera & & $\star(2)$ & $\star(1)$ & $\star$ & $\star$ & $\star(6)$ & $\star(6)$ & $\star$ & $\star$ \\
\hline & Heteroptera & & $\star(1)$ & NS & $\star$ & $\star$ & $\star(1)$ & $\star(1)$ & $\star$ & $\star$ \\
\hline & Thysanoptera & & NS & $\star(1)$ & $\star$ & $\star$ & $\star(2)$ & $\star(5)$ & $\star$ & $\star$ \\
\hline & Coleoptera & (adults) & NS & $\star(2)$ & $\star$ & $\star$ & $\star(4)$ & $\star(2)$ & $\star$ & $\star$ \\
\hline & Diptera & (adults) & $\star(2)$ & $\star(1)$ & $\star$ & $\star$ & $\star(3)$ & $\star(3)$ & $\star$ & $\star$ \\
\hline & Lepidoptera & (adults) & NS & $\star(1)$ & $\star$ & $\star$ & $\star(3)$ & $\star(2)$ & $\star$ & $\star$ \\
\hline & (larvae) & & $\star(1)$ & NS & $\star$ & $\star$ & NS & $\star(3)$ & $\star$ & $\star$ \\
\hline & Hymenoptera & (ants) & $\star(2)$ & NS & $\star$ & $\star$ & $\star(6)$ & $\star(6)$ & $\star$ & $\star$ \\
\hline & & (wasps) & $\star(2)$ & $\star(2)$ & $\star$ & 夫 & $\star(1)$ & $\star(3)$ & $\star$ & $\star$ \\
\hline
\end{tabular}

Under 'Species', the numbers in parentheses indicate how many of the seven sampling periods exhibited differences between the species. NS, not significant; NT, not tested. 
intercept traps). Recher et al. (1996b) observed that the phenologies of canopy arthropods were not necessarily in phase between sites of differing climatic patterns. Closer inspection of the Dryandra graphs indicates that the increase in abundance at intercept traps was delayed until spring, when compared with the Karragullen winter peak (cf. Figures $5 b$ and $6 b$ ), whereas the pattern at bark traps was bimodal, with the winter peak that was also found at Karragullen, plus a later spring peak (cf. Figs 5a and 6a). This could result from the favourability of bark habitat to saprovores during winter as a result of fungal and microbial activity, with an additional, later peak of different animals superimposed upon this pattern. This second 'flush' of invertebrates may represent animals from different trophic groups, such as herbivores, whose activity may be in phase with bark dwellers at Karragullen, but out of phase at Dryandra.

A third trend at both Karragullen and Dryandra was that invertebrate levels were not appreciably different between jarrah and marri, the two rough-barked species. This is not entirely surprising, because both tree species have bark of relatively similar thickness and chemical composition. In addition, trees that possess fissured or scaly bark of similar thickness tend to have similar thermal insulating properties (Nicolai 1986, 1995), creating environments that support similar densities and types of invertebrates. The brush-tailed phascogale, Phascogale tapoatafa, which predominantly feeds on arboreal invertebrates and eucalypt nectar, does not distinguish between jarrah and marri when foraging for bark-associated invertebrates (Scarff et al. 1998), further suggesting that the two species support similar abundances of bark invertebrates, at least of the kinds fed upon by phascogales.

The two smooth-barked species supported, and were visited by more invertebrates than the two roughbarked species. This is contrary to previous observations and predictions. Nicolai $(1986,1989)$ suggested that smooth-barked species provide fewer microhabitats than fissured or scaly barked trees, and that they also have less capacity to buffer the microclimate, leading to hotter, drier conditions at the bark surface. These predictions about microclimate have been confirmed for temperate forests in Europe (Nicolai 1986) and North America (Nicolai 1993), and in subtropical forest of South Africa (Nicolai 1989).

Why is there an opposite trend in Western Australia? Nicolai's findings have not always been supported. North American conifers with more structured bark supported fewer invertebrate species than those with poorly structured bark (Nicolai 1993), as did some thick-barked species in South African savanna (Nicolai 1989). Thus, the determination of invertebrate abundance and diversity is not determined solely by the thickness and structure of the bark, as illustrated by our results in Western Australia. It is possible that differences in bark nutrients or other compounds affects the abundance and kind of bark invertebrates, either by stimulating the growth of algae, bacteria and fungi or by inhibiting growth or repelling invertebrates. However, the data we obtained on bark nutrients are equivocal on this point.

At Karragullen and Dryandra, jarrah and marri grow on lateritic soils that are poor in nutrients (Churchward \& Dimmock 1989; McArthur 1991) and retain little water during summer. In contrast, wandoo and powderbark wandoo, by virtue of their lower position on the slope, occur on soils with more reliable moisture (McArthur 1991). Previous work demonstrated a correlation between the abundance and species richness of canopy arthropods, foliage nutrients and the level of soil nutrients. Jarrah, marri and other Western Australian eucalypts have less rich and abundant canopy faunas than eucalypts growing on richer soils in eastern Australia (Recher et al. 1996a). Foliage nutrient levels also tend to be lower on the poorer soils. This does not seem to be the explanation for the trends described here, because nutrient levels at Dryandra were not consistently higher in the soils associated with wandoo and powderbark wandoo, than with jarrah and marri. Possibly the greater availability of water, for longer periods throughout the year, allows a more abundant and rich invertebrate fauna to occur on the two smooth-barked species, but as there is little scope for water retention on these smooth-barked trees, any moisture effect must be derived from elsewhere in the woodland ecosystem.

Although many invertebrates reside on the trunks of trees and find shelter and food among the bark, a large number, if not the majority, of the arthropods trapped on tree trunks are likely to be derived from, or be dependent upon, the ground environment or the canopy (Majer et al. 2002). This is especially applicable to wandoo and powderbark wandoo, where the limited amounts of exfoliating bark provide little shelter relative to the thicker and highly structured barks of jarrah and marri. The derivation from, or dependence of the bark fauna on, the ground environment and/or canopy is because the canopy and the forest floor are where photosynthesis occurs and where energy captured by green leaves is released through the detritus cycle. We suspect that little photosynthesis occurs on the trunks of eucalypts in these relatively dry environments and that microbial and fungal activity (the detritus cycle) is similarly limited. A simple explanation for the richer and more abundant invertebrate faunas on the trunks of wandoo and powderbark wandoo than on jarrah and marri is that the wandoo woodlands have richer and more abundant canopy and ground faunas. Limited sampling by Majer and Recher (1988) showed that the canopy faunas of wandoo were richer than those of jarrah and marri, but we lack the data to show that this is related to differences in soil and foliage nutrients. 
Regardless of the reasons for differences in bark faunas between tree species or between Karragullen and Dryandra, the trends reported here highlight the importance of bark of each species of eucalypt as a habitat and resting place for a large array of invertebrates. Tree bark, and the range of species that produces it, should therefore be seen as an important source and location of forest biodiversity. This has particular implications for the way forests and woodlands are managed, since management practices such as prescribed burning (affecting soil/litter faunas and bark structure), selective logging (affecting tree age profile and tree species composition) and clearfelling (affecting tree age profiles) have the potential to influence bark-associated invertebrates and to restrict the movement of invertebrates through the forest ecosystem.

\section{ACKNOWLEDGEMENTS}

This work was funded by a grant from the Australian Research Council (ARC). Staff from the Mundaring office of the Department of Conservation and Land Management are thanked for assisting us with the selection of sites. Brian Heterick and Chris Norwood assisted us with varying aspects of the field and laboratory work. Jacob Friedman and Susan Rhind, and two anonymous referees kindly commented on an earlier draft of this paper.

\section{REFERENCES}

André H. M. (1985) Associations between corticolous microarthropod communities and epiphytic cover on bark. Holarctic Ecol. 8, 113-19.

Baehr M. (1990) The carabid community living under bark of Australian eucalypts. In: The Role of Ground Beetles in Ecological and Environmental Studies (ed. N. E. Stork) pp. 3-11. Intercept, Hampshire.

Brooker M. I. H. \& Kleinig D. A. (1990) Field Guide to Eucalypts: Vol. 2. South-Western and Southern Australia. Inkata Press, Melbourne.

Buchs W. (1990) On the importance of tree trunks as a habitat of arthropods and other invertebrates. Z. Fuer. Angewandte Zool. 77, 453-78.

Calver M. C. \& Wooller R. D. (1982) A technique for assessing the taxa, length, dry weight and energy content of the invertebrate prey of birds. Aust. Wildl. Res. 9, 293-301.

Churchward H. M. \& Dimmock G. M. (1989) The soils and landforms of the northern jarrah forest. In: The farrah Forest (eds B. Dell, J. J. Havel \& N. Malajczuk) pp. 13-21 Kluwer Academic Publishers, Dordrecht.

Funke W. (1977) Die stammregion von wäldern: Lebensraum und durchgangszone von arthropoden. Verhandlougen Deutschen Zool. Gesellschaft 1977, 244.

Gowing G. \& Recher H. F. (1984) Length-weight relationships for invertebrates from forests in south-eastern New South Wales. Aust. F. Ecol. 9, 5-8.
Gowing G. \& Recher H. F. (1985) Further comments on lengthweight relationships of invertebrates. Aust. F. Ecol. 10, 195.

Gullen P. J. \& Strong K. L. (1997) Scale insects under eucalypt bark: A revision of the Australian genus Phacelococcus Miller (Hemiptera: Coccoidea: Eriococcidae). Aust. F. Entomol. 36, 229-40.

Hanula J. L. \& Franzreb K. (1998) Source, distribution and abundance of macroinvertebrates on the bark of longleaf pine: Potential prey of Red-cockaded Woodpecker. For. Ecol. Manage. 102, 89-102.

Hanula J. L., Franzreb K. E. \& Pepper W. D. (2000) Longleaf pine characteristics associated with invertebrates available for Red-cockaded Woodpeckers. F. Wildl. Manage. 64, 60-70.

Heterick B. E., Majer J. D., Recher H. F. \& Postle A. C. (2001) A checklist of the canopy, bark, soil and litter fauna of the Darling Plateau and adjacent woodland near Perth, Western Australia, with reference to the conservation of forest and woodland fauna. Curtin Uni. Technol. School Environ. Biol. Bull. 21, 1-35.

Jackson J. A. (1979) Tree surfaces as foraging substrates for insectivorous birds. In: The Role of Insectivorous Birds in Forest Ecosystems (eds J. G. Dickson, R. N. Conner, R. R. Fleet, J. C. Kroll \& J. A. Jackson) pp. 69-94. Academic Press, New York.

Levy E. G. \& Madden E. A. (1933) The point method of vegetation analysis. NZ F. Agric. 46, 267-79.

McArthur W. M. (1991) Reference Soils of South-Western Australia. Western Australian Department of Agriculture, Perth.

Majer J. D. \& Recher H. F. (1988) Invertebrate communities on Western Australian eucalypts: A comparison of branch clipping and chemical knockdown procedures. Aust. F. Ecol. 13, 269-78.

Majer J. D., Recher H. F. \& Ganesh S. (2000) Diversity patterns of eucalypt canopy invertebrates in eastern and western Australia. Ecol. Entomol. 25, 295-306.

Majer J. D., Recher H. F., Heterick B. E. \& Postle A. C. (2002) The canopy, bark, soil and litter invertebrate fauna of the Darling Plateau and adjacent woodland near Perth, Western Australia, with reference to the diversity of forest and woodland invertebrates. Pac. Conserv. Biol. 7, 229-39.

Moeed A. \& Meads M. J. (1983) Invertebrate fauna of four tree species in Orongorongo Valley, New Zealand, as revealed by trunk traps. NZ F. Ecol. 6, 39-53.

Nicolai V. (1986) The bark of trees: Thermal properties, microclimate and fauna. Oecologia 69, 148-60.

Nicolai V. (1989) Thermal properties and fauna on the bark of trees in two different African ecosystems. Oecologia 80, $421-30$.

Nicolai V. (1993) The arthropod fauna on the bark of deciduous and coniferous trees in a mixed forest of the Itasca State Park, MN, USA. Spixiana 16, 61-9.

Nicolai V. (1995) The ecological significance of trees' bark during ecosystem dynamics. Spixiana 18, 187-99.

Proctor H. C., Montgomery K. M., Rosen K. E. \& Kitching R. L. (2002) Are tree trunks habitats or highways? A comparison of oribatid mite assemblages from hoop-pine bark and litter. Aust. F. Entomol. 41, 294-9.

Recher H. F., Majer J. D. \& Ganesh S. (1996a) Eucalypts, insects and birds: On the relationship between foliar nutrients and species richness. For. Ecol. Manage. 85, 177-95.

Recher H. F., Majer J. D. \& Ganesh S. (1996b) Seasonality of canopy invertebrate communities in eucalypt forests of eastern and western Australia. Aust. F. Ecol. 21, 64-80. 
Scarff F. R., Rhind S. G. \& Bradley J. S. (1998) Diet and foraging behaviour of brush-tailed phascogales (Phascogale tapoatafa) in the jarrah forest of south-west Australia. Wildl. Res. 25, 511-26.
Simon U. (1991) Temporal species series of web-spiders (Arachnida: Aranea) as a result of pine tree bark structure. Bull. Société Sci. Nat. Neuchâtel 116-1, 223-7. 